八゚球に対する抗原提示細胞で，遅延型アレルギー反応 の成立に作用している，今回の実験結果から以下の考 察を行った. 1.ランゲルハンス細胞、Tリンパ球の分 布から基底層ことに乳頭の部分が抗原提示において重 要な部位であることが推定された。2，回腔扁平苔㴶に
おいて粘膜固有層に多数の Tリンパ球浸潤が認めら れ、ランゲルハンス細胞も多数出現していることから， 局所において遅延型アレルギ一反応が盛んに行われて いることが示暧された。

\title{
241. パルス電気泳動を用いたウイルス感染症の実験室内診断
}

青地克也・川上晋一郎・增田 游（岡山大） 荒尾雄二郎・新居志郎（同・ウイルス）

目的 ウイルス感染症の実験室内診断を簡便化する 目的で，臨床材料からのウイルスDNA 検出にパルス フィールドグラディエント電気泳動（PFG）の応用を 試みた。

万法 i) PFGによるウイルスDNAの検出：単 純へルペスウイルス (HSV) または水痘・帯状疮疹ウ イルス (VZV) 感染症の疑いをもたれた73症例の患者 から皮㲊病巣部の組織（水疮蓋，膿疮葢，痂皮）を約 1〜4mm² 採取した。これをダウンスのホモジェナイザ 一で磨砕した後, $0.5 \%$ 低融点アガロースに包埋した状 態で除蛋白処理し,PFGで分析した.PFGとしては, フィールドインバージョンゲル電気泳動を用いた（電 圧：約 $5 \mathrm{~V} / \mathrm{cm}$, 泳動層内温度 : 約 $13^{\circ} \mathrm{C}$, パルス間隔: 正 9 秒, 逆 3 秒，休止 1 秒, 泳動時間：20時間). PFG 後の DNA は, EtBrで染色し, 紫外線下で写真撮影し た. ii）虽光抗体 $(\mathrm{FA})$ 法によるウイルス抗原の検出： 上記の73症例中，65症例の患者加ら患部塗抹材料を採 取し,FA 法によるウイルス抗原の検出を試みた.VZV 抗原の検出には直接営光抗体法を, HSV 抗原の検出
には直接蛍光抗体法と間接蛍光抗体法を用いた。

結果 i）上記の73症例について, PFG 法によるウ イルス DNA 検出を試み，64症例 $(88 \%$ ) からウイルス DNA 老検出した， ii）上記の73症例中，PFG法によ るウイルス DNA 検出と併せて FA 法によるウイルス 抗原検出を試みた65症例において，ウイルス抗原検出 率 $(85 \%)$ とウイルス DNA 検出率 $(86 \%)$ は同程度て あった。 iii） ii）の症例中，FA 法によりウイルス抗原 陰性と判定された10症例について, PFG 法によるウイ ルス DNA 検出で， 2 症例から HSV・DNA が，6症 例加ら VZV・DNA を検出した.

結論 i ) PFGを用いたウイルスDNA 検出法に より，微量な臨床材料から簡便に，HSV およびVZV 感染症の実験室内診断を行うことができた。 ii） PFG を用いたウイルスDNA 検出法はFA 法と同様に高い 検出感度を有していた。 iii） PFGを用いたウイルス DNA 検出法はFA 法の補完的役割をはたすことがで きた。

\section{2. 睡眠時無呼吸症候群（OSA）における}

\section{上気道の狭窄部位について}

\section{大木幹文・長谷川誠（東医雬大）}

Philip Cole - James Haight (Sleep Study Clinic, Univ. of Toronto)

\begin{abstract}
睡眠時における呼吸異常に関する研究が進められ、 睡眠時無呼吸症候群に対する病態生理の解明，および 治療法が検討されている。中でも，閉塞型睡眠時無呼 吸症候群 (OSA) は，上気道の狭窄が主な原因と考え られる。攵の狭窄部位の特定については，これまでに も，内視鏡，X-P, CT スキャンなどにより検討されて きたが，これらの方法は，覮醒時に行われる場合が多 く，必ずしも，睡眠時の呼吸動態を反映している上は 限らない. 今回, Millar力テーーテル压トランスデュー サを用い，睡眠中の患者に，上気道の呼吸压を段階的 に測定し，狭窄部位を同定する方法を試みた。
\end{abstract}

対象としたのは，睡眠障害を主訴として，St．Mi chael's Hospital $\sigma$ Sleep Study Clinic (Univ. of Toronto)を紹介さ机た患者に，事前に，睡眠テストを
施行し，OSA と診断された患者30名(男28名，女 2 名) で, 軽度の肥渵を訴え, Apnea の程度も中等度以上て あった。２本の Millarカテーテル (米, Millar 社製) を用い，1本を鼻咽腔に固定し，もう1本は中咽頭に 插入し，単純 X-Pでトランスデューサの位置を確恝。 中咽頭に扱入したカテーテルを $1 \mathrm{~cm}$ ずつ引き出し, 無 呼吸発作中の鼻咽腔に㧍ける压波形と比較した。中咽 頭に挿入したカテーテルの压トランスデューサが, 気 道狭窄部に支る場合，無呼吸発作中も中咽頭の呼吸压 変化は測定できるが，気道狭窄上部にある場合は，無 呼吸時の圧变化は，鼻咽腔と同様に，無変化となる。 そこで，中咽頭に插入したカテーテルの呼吸圧変化パ ターンが変化する位置を気道㹨窄部位と特定した。 の結果，狭窄部位は，軟口蓋が 17 例 $(56 \%)$ 舌根部が 